interaction between investigative and operational units is carried out in the following organizational forms: 1) exchange of information; 2) joint discussion of opinions, proposals, conclusions on the materials of the proceedings and on issues of interaction; 3) joint planning; 4) joint participation in carrying out separate investigative (search) actions.

It has been concluded that the effective procedural interaction of the investigator with the operational units during the search as part of the investigative task force is characterized by the following features: 1) the search has the same purpose; 2) all actions of the members of the investigative task force must be agreed upon during the development of a single plan; 3 ) each of the members of the investigative task force acts within its powers and retains its functional independence; 4) work as a member of the investigative task force gives the investigator the opportunity to use the data obtained promptly as soon as possible, and to operational officers the information obtained during the search (in compliance with the principles of strict confidentiality)

Keywords: interaction, investigator, search, operative subdivisions, prosecutor, criminal proceedings.

UDC 549.08+549.211

DOI 10.31733/2078-3566-2021-1-298-302

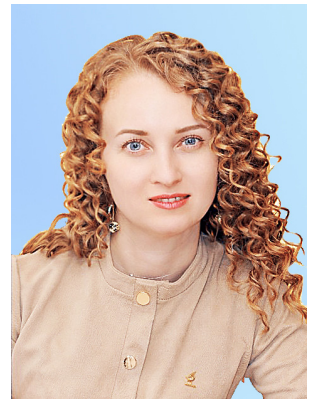

Iryna RUDENKA ${ }^{\odot}$

Senior Forensic Expert

(Research and Expert Forensic Center of the Ministry of Internal Affairs of Ukraine)

\title{
CURRENT TRENDS IN THE DEVELOPMENT \\ OF SCIENTIFIC AND TECHNICAL TOOLS FOR THE RESEARCH OF JEWELERY WITH INSERTS OF PRECIOUS STONES
}

У роботі проаналізовано нові наукові знання щодо природи походження дорогоцінного каміння і його синтетичних аналогів та імітацій, здійснено огляд існуючих технологій, сучасних приладів для діагностики, а також наведено результати власних досліджень. Зазначено, що за допомогою приладу DiamondView виявляються ростові рисунки, характерні для різних типів природних та синтетичних діамантів, що забезпечує якісну діагностику природних і синтетичних діамантів, різних способів облагородження, а також рубінів і сапфірів та іншого дорогоцінного каміння. Розроблений De Beers скринінговий пристрій DiamondView дозволяє точно визначити підписи про підвищення температури синтетичного синтезу НРНТ та різну структуру кристалів. Констатовано, що діагностика зразків алмазів, синтезованих за НРНТ-технологією за допомогою приладу DiamondView, здебільшого не викликає труднощів за умови правильного встановлення та орієнтації досліджуваного зразка виявлення структурних рисунків, притаманних штучним алмазам.

Зроблено висновок про те, що наразі недостатня увага приділяється проблемам створення гемологічних лабораторій, закупівлі гемологічного обладнання, підготовці експертів за експертною спеціальністю 17.1. «Дослідження дорогоцінного, напівдорогоцінного та декоративного каміння», тобто дослідження, що дозволяє ідентифікувати гемологічний об'єкт; встановити походження досліджуваного об'єкта; визначити геометричні розміри, вагу, вид і тип огранювання чи обробки, дослідити властивості, якісні ознаки, наявність чи відсутність облагородження та на основі визначених параметрів установити вартість досліджуваного об'єкта.

Ключові слова: дорогоцінне каміння, напівдорогоцінне камиіння, судово-гемологічна експертиза, експерт, діамант, рубін, сапфір, облагородження, синтетичне каміння, флюоресиенція.

Introduction. Precious metals and precious stones are a special type of tangible assets as well as an important component of economic development and sustainability of any state. Therefore, the problem of using scientific as well as technical means and methods in the investigation of the illicit market of precious metals, precious, and semiprecious stones is one of the most important in modern criminology.

Literary review. The doctorate and monographic works of domestic and foreign scientists A.I. Vinberg, R.S. Bielkin, G.I. Gramovich, L.G. Granovsky, I.M. Luzgin, V.I. Gromov, V.I. Goncharenko, M.A. Selivanov, V. Ya. Koldin, V.I. Shikanov, I.M. Yakimov etc. were devoted to

(C) Rudenka I. O., 2021

ORCID ID https://orcid.org/0000-0002-5180-3597

tabloid@i.ua 
the theory and practice of technical and forensic support of crime investigation. The results of the research on certain areas of technical and forensic activities, organization, and legal regulation of the special knowledge usage as well as implementation of scientific and technical means for this purpose were covered in the works of V.D. Arseniev, E.I. Zuev, Ye.P. Ishchenko, M.K. Kaminsky, V.S. Mitrichiev, M.S. Poliovy, V.A. Snietkov etc.

The development of legal regulation for precious metals and precious stones circulation is considered in the scientific works of the researchers in different periods, in particular S.T. Goncharuk, K.M. Semeniuk, L.P. Makarov, M.M. Nazimka, A.M. Ivanov, M.M. Postnikov-Losiev, N.G. Platonov, B.L. Ulianov, D.V. Zub, I.P. Eisenberg, K.V. Yefremov, O.M. Malichenko, Yu.L. Chernosvitov, M.I. Zatulkin, O.L. Almazova, L.A. Dubonosov, A.E. Abalov, M.S. Marfunin, Yu.O. Titova etc. At the same time, it can be noted that in modern forensic science the outlined issues are quite fragmented and sporadical.

Objectives of the study. According to forensic practice, nowadays there is a tendency to an increase in the number of crimes committed where the subject of the criminal assault or means of committing the crime were jewelry with inserts of precious stones. Therefore, the purpose of this study is to consider the main trends in the development of forensic tools for the study of jewelry with inserts of precious stones, including the use of special diagnostic technologies during the examination of precious stones in raw materials and in processed forms. To achieve this goal, we considered such a forensic tool as DiamondView TM which allows to distinguish natural precious stones from their synthetic counterparts with a high degree of reliability.

Materials and methods. These days increasing criminalization of the society, as evidenced by forensic and expert practice, leads to crimes at the illicit market of precious metals, precious and semiprecious stones, and the ways of their commission and concealment as well as the use of new technical devices are improving. The presented study shows that currently insufficient attention is paid to the problems of creating gemological laboratories, procurement of gemological equipment, training of experts in the expert specialty 17.1. Study of Precious, Semi-Precious and Decorative Stones, i.e. a kind of research that allows to identify a gemological object, establish the origin of the object under study, determine the geometric dimensions, weight, type of faceting or processing, investigate the properties, quality characteristics, presence or absence of refinement and on the basis of certain parameters to determine the value of the object under study.

Diagnostics of diamonds with the help of DiamondViewTM device. As jewelry made of artificial diamonds appeared at the market, a need for their reliable diagnostics became topical [1-4].

In the 2000s De Beers developed a simple but effective device - DiamondView TM which allowed to distinguish natural diamonds from their synthetic counterparts with a high reliability.

DiamondView TM is a small device 26x24x44 cm weighing $13 \mathrm{~kg}$. The device works with jewelry inserts and products ranging in size from 0.05 to 10 carats. The device is quite easy to use. After opening the door, a sample is installed in a vacuum bowl where it is held by a special pump. After closing the door, the camera installed in the device is automatically turned on and the expert can observe the sample on the monitor screen.

With the help of rotating handles which are located on the outside of the device it is possible to adjust the image of the sample depending on the needs of the expert. The handles allow to move the sample vertically, horizontally, rotate around its axis, and adjust the focus.

The device is based on the irradiation of the sample with UV waves $225 \mathrm{~nm}$ long (short waves). When irradiated, the fluorescence of the sample is observed, phosphorescence is automatically recorded, visible growth structures which reflect the conditions of the diamond crystallization become visible.

This device allows to analyse both natural diamonds and diamonds obtained by different methods of synthesis:

- determination of diamonds, refined with HPHT-method (processing at high pressure and temperature), natural and synthetic diamonds: colorless, blue, yellow, and their diagnostics;

- diagnostics of yellow diamonds refining;

- diagnostics of CVD-diamonds (diamonds over 0.15 carats), including pink ones [5, p. 74].

In addition, with the mentioned device one can determine:

- the nature of the colour for pink, green, fancy brown, and blue diamonds;

- the form of the filler in emeralds;

- Be-diffusion in reddish orange and blue sapphires;

- deep Ti-diffusion in blue sapphires;

- diagnostics of heat treatment for sapphires;

- diagnostics of flux filling for rubies;

- the difference of synthetic flux alexandrites from rubies and sapphires; 


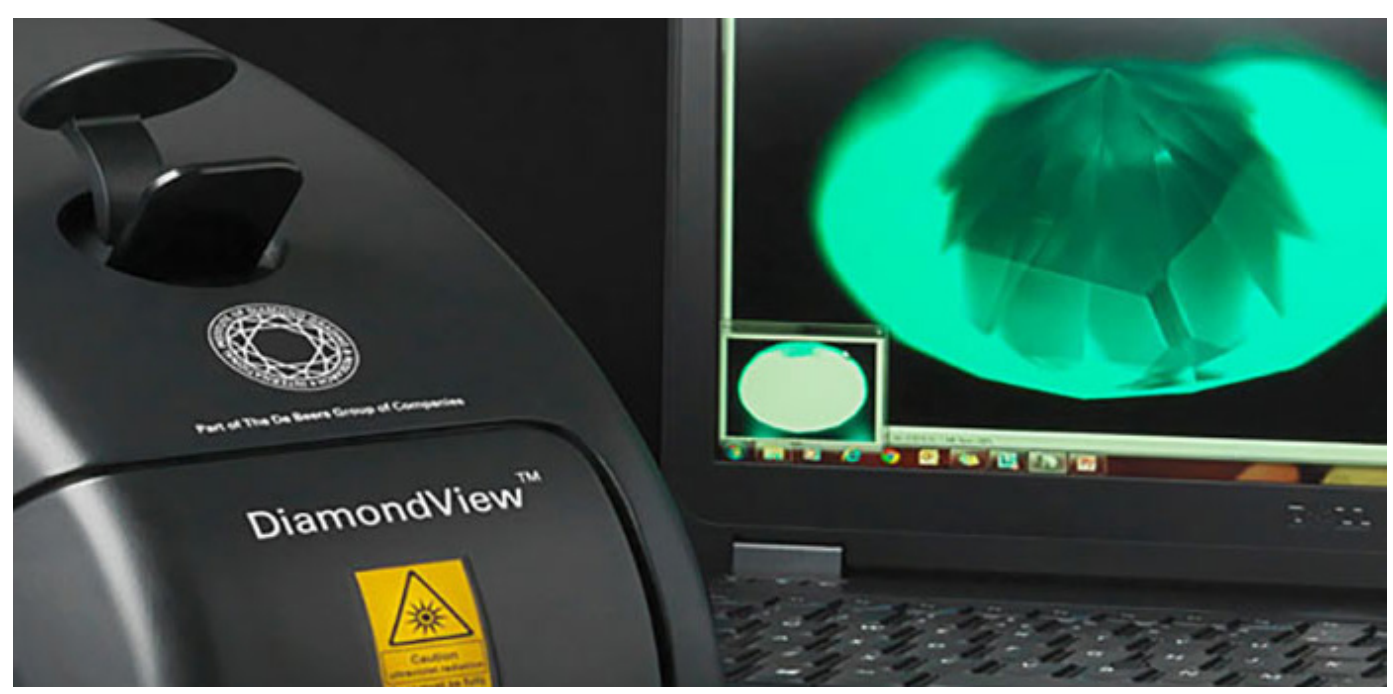

Fig. 1. DiamondView device and the type of the diamond fluorescence on the computer monitor [6].

- alexandrite - natural / synthetic;

- noble opal - the difference between natural and synthetic;

- determination of $\mathrm{Cu}$-containing tourmalines and Paraiba-tourmalines;

- the difference between cultivated and natural pearls as well as between cultivated sea pearls and freshwater ones;

- diagnostics of fixed coloured stones using express spectrometry.

HPHT (High Pressure High Temperature) artificial synthetic diamonds which reproduce the natural process of diamond formation were the first synthetic materials developed in the 1950s for industrial use. De Beers created the first synthetic precious stone for research in the 1980s.

Synthetic HPHT diamonds are grown in a press with a camera in the middle. A seed crystal is placed in the lower part of the chamber coated with a metal solvent catalyst. Graphite powder is placed over a metallic solvent, then the mixture is subjected to extreme pressure and the temperature of 1300 to 1500 degrees Celsius - slightly higher than the heat that generates natural diamonds.

Different features of growth in natural and laboratory conditions determine the formation of the synthetic composition of HPHT-diamonds in different ways. These are mostly cubo-octahedral forms while in natural conditions there are octahedral or dodecahedral forms. The process often leaves indicators of metal inclusions in the stone, some of which react to a strong neodymium magnet. These inclusions can be detected visually or with a microscope.

Other identification characteristics include zonal colouring, especially around the culet that is associated with crystal growth characteristics, and distinctive greenish fluorescence.

Although visual observations may indicate that the diamond is synthetic, devices such as DiamondCheck (GIA), DiamondSure, and DiamondView (De Beers) use spectral, photoluminescence analysis, and / or phosphorescence analysis to identify stones that are synthetic more accurately.

Developed by De Beers, the DiamondView screening device allows to identify signatures about the increase in the temperature of the synthetic synthesis of HPHT and different crystal structureb accurately. In addition, as these synthetic substances were subjected to increased heating for several days rather than millions of years, another De Beers screening device, DiamondSure, may detect differences in how nitrogen impurities are configured within the stone.

Nowadays several new manufacturers create high-quality synthetic materials, including fancy blue, colourless, and fancy yellow diamonds. The largest HPHT diamond ever studied by GIA weighs more than 4 carats. The Russian manufacturer, New Diamond Technology, produced colourless and almost colourless HPHT diamonds weighing 5 carats.

Over the last decade a new process for producing synthetic diamonds by chemical vapour deposition (CVD) has developed rapidly. Gases, usually methane and hydrogen, are heated with microwaves to form plasma that deposits carbon atoms on the substrate which later crystallizes as a diamond. After growth, synthetic diamonds are turned into cubes or cylinders.

Unlike HPHT diamonds, CVD diamonds do not have distinctive inclusions, so these diamonds can be identified by infrared spectroscopy or by using the DiamondSure device which allows to detect their absorption features. The final identification can be made using DiamondView 
which reveals differences in the fluorescence patterns of CVD diamonds. In addition, while some CVD diamond-specific emission lines can be removed by annealing (high-temperature heat treatment), excessive silicone impurities which are very common in currently available stones of this type (and very rare in natural diamonds) are extremely difficult to remove.

The DiamondView device examines surface fluorescence by illuminating the stone with shortwave ultraviolet light. The corresponding image can be viewed on the screen, and it can be concluded whether this stone is natural or synthetic.

Unfastened polished stones are held in place by a vacuum holder. A modified holder is available for large stones. You can also look at some prefabricated items, such as earrings with stone inserts and simple rings, by changing the assembly of the holder using the provided adapters. The colour and pattern of fluorescence as well as the absence or presence of phosphorescence will vary depending on the natural or synthetic origin of the stone. To help the user interpret the characteristics of synthetic CVD diamonds that have blue fluorescence, there are easily modified filters that improve the understanding of the growth characteristics of synthetic stones.

The following growth patterns typical of different types of natural and synthetic diamonds can be detected with the help of DiamondView.

One of the biggest problems that sales professionals and gemologists currently face is the need to determine exactly whether the stone was heat treated. Although a reliable answer to this question is a job for a large laboratory, there is a simple and inexpensive tool that can often give an important indication. This is an ultraviolet lamp with the use of microscopic examinations.

With the help of special filters (for example, the blue-green Schott BG-12 filter) it is possible to dampen red fluorescence and on the contrary strengthen the transfer of titanium Ti 4+ blue fluorescence.

In another heat-treated and flux-saturated ruby from Mong Hsu (Burma), thin zonal spots of chalk blue fluorescence "float" on the fluorescence of a red body based on chromium $\mathrm{Cr} 3+$. These areas are strong evidence of high-temperature heat treatment but are masked by red fluorescence, so they are difficult to see. However, the same filter helps to get rid of red fluorescence.

\section{Conclusions.}

The analysis of the existing technologies and instrumental methods for the research of precious stones in the natural and refined state, its synthetic analogues and imitations as well as our own research allow to make the following conclusions:

1. One of the methods that provides comprehensive information on the origin and methods of refining precious stones is the use of fluorescence in short and long waves with the subsequent studies of the magnified image.

2. For scientific tasks and teaching the basics of methodological research, it is possible to use inexpensive devices (an ultraviolet lamp or a specialized flashlight pen, a digital microscope) with the subsequent display of the research results on the computer monitor.

3. Professional examination requires appropriate equipment. DiamondView is the device that provides high-quality diagnostics of natural and synthetic diamonds, various methods of refining as well as rubies, sapphires, and other precious stones.

4. Diagnostics of diamond samples synthesised by HPHT technology using the DiamondView device in most cases does not cause difficulties provided that the sample is identified and oriented correctly to detect structural patterns intrinsic to artificial diamonds.

\section{Список використаних джерел}

1. Пагель-Тайсен В. Все об оценке бриллиантов: Практич. пособие. - Изд. 9, перераб. и доп. / Пер. с англ. Т.В. Калюжной. - Донецк; Днепропетровск: АРТ-ПРЕСС, 2008. 324 с.

2. Солодова Ю.П., Николаев М.В., Курбатов К.К. и др. Геммология алмаза: Учебник. - М., 2008. 416 с.

3. Шуман В. Драгоценные и полудрагоценные камни: Пер. с нем. - М.: БММ АО, 2006. 312 с.

4. Diamond View User Manual. - Diamond Trading Company Ltd, 2008. 81 p.

5. Antoinette Matlins, Antonio C. Bonanno. Gem Identification Made Easy - Gemstone Press, Woodstock, Vermont, 2014. - $378 \mathrm{p}$.

6. Russell Shor. Synthetic Diamonds Getting Better, But so is Detection // GIA News\&Research. - April 2015. - Режим доступу: https://www.gia.edu/gia-news-research/basel-gemfest-synthetic-diamondsdetection.

Надійшло до редакиії 11.03.2021

\section{References}

1. Pahel-Taisen V. Vse ob otsenke bryllyantov: Praktych. posobye. - Yzd. 9, pererab. y dop. / Per. s anhl. T.V. Kaliuzhnoi. - Donetsk; Dnepropetrovsk: ART-PRESS, 2008. 324 s. [in Ukr.]

2. Solodova Yu.P., Nykolaev M.V., Kurbatov K.K. y dr. Hemmolohyia almaza: Uchebnyk. - M., 2008. 
416 s. [in Russ.]. [in Russ.]

3. Shuman V. Drahotsennыe y poludrahotsennыe kamny: Per. s nem. - M.: BMM AO, 2006. 312 s.

4. Diamond View User Manual. - Diamond Trading Company Ltd, 2008. 81 p.

5. Antoinette Matlins, Antonio C. Bonanno. Gem Identification Made Easy - Gemstone Press, Woodstock, Vermont, 2014. - 378 p.

6. Russell Shor. Synthetic Diamonds Getting Better, But so is Detection // GIA News\&Research. April 2015. https://www.gia.edu/gia-news-research/basel-gemfest-synthetic-diamonds-detection.

\title{
SUMMARY
}

Iryna O. Rudenka. Current trends in the development of scientific and technical tools for the research of jewelery with inserts of precious stones. The paper analyses innovative scientific knowledge concerning the origin of precious stones as well as their synthetic analogues and imitations. Besides, the existing technologies and modern diagnostic devices are reviewed and the results of our own research are presented.

Methods of fluorescence analysis and research under a microscope in the study of natural precious stones, including refined ones as well as their synthetic analogues and imitations is demonstrated.

Keywords: precious stone, diamond, HPHT, CVD, ruby, sapphire, refinement, synthetic stones, fluorescence, phosphorescence.

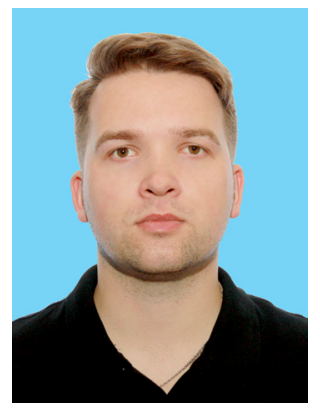

\author{
Yehor SHARAI ${ }^{\circ}$ \\ (State Research expert forensic center \\ of the Ministry of Internal Affairs of Ukraine)

\section{CONDITION OF SCIENTIFIC RESEARCH INVOLVEMENT OF EMPLOYEES OF THE EXPERT SERVICE OF THE MINISTRY OF INTERNAL AFFAIRS OF UKRAINE TO THE PRE-TRIAL INVESTIGATION}

В статті розглянуто стан наукових досліджень з питань залучення працівників Експертної служби МВС України до досудового розслідування.

Відзначено, що розширення та поглиблення наукових досліджень в галузі судово-експертної діяльності неминуче призводить до потреби використання таких досягнень і в практичній діяльності органів внутрішніх справ України.

Автором проаналізовані окремі наукові дослідження, здійснені у формі докторських, кандидатських дисертацій, монографій, низка наукових статей, навчально-методичних матеріалів, що дає підстави для висновку про те, що питання взаємодії експертів зі слідчими, оперативними працівниками, захисниками, використання ними спеціальних знань у своїй діяльності, а також залучення працівників Експертної служби МВС України до досудового розслідування в умовах сучасного змагального кримінального процесу викликають інтерес у багатьох вітчизняних і зарубіжних науковців та практиків.

Підкреслено, що потребують подальшого наукового розроблення питання криміналістичних рекоменлдацій щодо збирання та надання необхідних матеріалів з підготовки та призначення експертиз в межах міжнародної правової допомоги.

Крім того, автором констатовано, що аналіз окремих наукових досліджень, здійснених у формі докторських, кандидатських дисертацій, монографій, низки наукових статей, навчально-методичних матеріалів дає підстави для висновку про те, що питання залучення експертів Експертної служби МВС до досудового розслідування в умовах сучасного змагального кримінального процесу викликають інтеpec у багатьох вітчизняних і зарубіжних науковців і практиків. Багатогранність проблематики, широта інтересів користувачів до розвитку наукової думки й досягнень науково-технічного прогресу, важливість завдань, які виконують працівники Експертної служби МВС вказують на актуальність цієї про-

(C) Sharai Y. V., 2021

ORCID ID https://orcid.org/0000-0002-3932-3435

sharayegor@gmail.com 